\title{
PENGARUH TRUST DAN PENERIMAAN TEKNOLOGI TERHADAP MINAT KONSUMEN DALAM PEMBELIAN ONLINE (Studi kasus www.kaskus.us)
}

\author{
Adi Triatma \\ Fakultas Ekonomi Universitas Islam Indonesia \\ Fitriati Akmila \\ Fakultas Ekonomi Universitas Islam Indonesia \\ e-mail: akmila_f@yahoo.com
}

\begin{abstract}
This study discusses the impact of trust and the acceptance of technology on consumer intention to purchase on line at www.kaskus.us. The focus of the study was to test whether privacy, security, trust, risk perceived usefulness and ease of use influence student intention to purchase online. The sample taken are from Accounting Department Universitas Islam Indonesia students who purchase on line at the web site kaskus.us. The data were analyzed using multiple regression and SEM, then calculated with SmartPLS software. The results indicate that privacy and security have positive influence ontrust. Moreover, perceived usefulness and ease of use have positive and significant effect on interest in purchasing online. On the contrary trust have negative effect on the risk to buy online. Lastly, risk have negatively effect and not significant with the intention to purchase on line.
\end{abstract}

Keywords: security, privacy, trust, risk, perceived usefulness, perceived ease of use, intention, online purchase

\section{PENDAHULUAN}

Sistem informasi berbasis internet banyak digunakan saat ini. Internet juga merupakan media yang paling ekonomis untuk digunakan sebagai basis sistem informasi. Disamping itu menjamurnya perusahaan penyedia layanan koneksi internet dan semakin terjangkaunya gadget canggih yang mendukung akses internet memudahkan semua kalangan masyarakat untuk menjangkau media tersebut. Alasan-alasan di atas menyebabkan internet menjadi salah satu media elektronik yang populer untuk menjalankan bisnis, yang kemudian dikenal dengan istilah electronic commerce atau ecommerce. E-commerce merupakan penggunaan jaringan komputer untuk melakukan pembelian dan penjualan barang, jasa dan informasi secara elektronis (Urbaczewski et al, 2002). Amazon.com, e-bay dan kaskus.us adalah contoh perusahaan yang sukses melakukan perdagangan secara elektronik melalui jaringan internet.
Di Indonesia transaksi bisnis melalui internet merupakan suatu fenomena bisnis baru. Banyak situs yang menawarkan barang atau jasa via internet seperti selulershop.co.id dan globalteleshop.com yang menjual tablet PC dan telepon seluler, bhinneka.com dan glodokshop.com yang menjual komputer dan barang-barang elektronik. Selain besarnya manfaat yang dihasilkan, internet merupakan sistem jaringan komputer yang memiliki kerentanan (vulnerable). Software bug, hardware bug, serangan cracker dan hacker merupakan sumber kerentanan sistem internet yang dapat memicu kegagalan sistem dan kerusakan.

Masa depan business-to-consumer ecommerce (EC) bergantung pada kepercayaan konsumen terhadap retailer web dan terhadap teknologi internet. Kepercayaan (trust) menjadi dasar bagi transaksi penjual dan pembeli yang membuat konsumen memiliki harapan besar untuk puas 
terhadap hubungan tukar-menukar tersebut (Pavlou, 2003). Kepercayaan (trust) terhadap electronic vendor menentukan putusan konsumen untuk melakukan hubungan penyedia bisnis e-commerce (Friedman et al. 2000).

Pemisahan spasial dan temporal antara konsumen dan retailer web yang diberlakukan oleh infrastruktur internet menghasilkan risiko implisit seputar transaksi online (Brynjolfsson dan Smith, 2000). Pembeli online harus bergantung pada informasi elektronik tanpa memeriksa secara fisik produk fokal. Maka, ada risiko tambahan karena berpotensi menimbulkan informasi yang tidak lengkap yang diberikan oleh retailer web (Lee, 1998). Selain itu, sifat terbuka internet sebagai media transaksi dan sifat tidak diatur secara global menciptakan risiko tambahan untuk konsumen online, menjadikan kepercayaan sebagai elemen penting dari EC (Hoffman, Novak, dan Peralta, 1999). Ketidakpastian yang melekat di e-commerce membuat para peneliti berargumen bahwa membangun kepercayaan (trust) dan memperkecil risiko menjadi faktor paling penting dalam bertransaksi di e-commerce (Pavlou, 2003, Gefen et al. 2003, Jarvenpaa dan Tractinsky, 1999, McKnight et al, 2002). Oleh sebab itu, persepsi kepercayaan, risiko, privasi, dan keamanan menjadi fundamental untuk masa depan EC.

Teori mengenai adopsi dan penggunaan teknologi internet dapat dijelaskan dengan menggunakan konstruksi Technology Acceptance Model (TAM) (Davis, 1989). TAM semula difokuskan pada penggunaan sistem dalam lingkungan kerja, penelitian terbaru telah berusaha untuk menggunakan TAM untuk memahami penggunaan website (Moon dan Kim, 2001). Oleh karena itu, niat untuk menggunakan internet untuk transaksi online bisa mengambil teori konstruksi utama TAM, terutama menyangkut manfaat dan kemudahan penggunaan yang dirasakan.

Penelitian ini merupakan penelitian yang diadopsi dari Paul Pavlou (2001). Per- bedaan antara penelitian ini dengan penelitian sebelumnya terletak pada tempat dan sampel penelitian. Penelitian ini dilakukan di Fakultas Ekonomi Universitas Islam Indonesia, dengan sampel mahasiswa prodi akuntansi. Permasalahan utama yang muncul dalam penelitian ini adalah: Apakah kepercayaan (trust), persepsi keamanan, privasi, risiko, persepsi kegunaan, dan kemudahan penggunaan berpengaruh pada minat konsumen untuk melakukan transaksi online?. Artikel ini disusun dengan sistematika sebagai berikut. Dimulai dengan pendahuluan, tinjauan pustaka dan perumusan hipotesis, metode penelitian, analisa data, dan terakhir kesimpulan.

\section{TINJAUAN PUSTAKA DAN PERUMUSAN HIPOTESIS} www. kaskus.us

E-commerce adalah lingkungan digital yang memungkinkan transaksi komersial terjadi diantara banyak organisasi dan individu. Dalam lingkungan e-commerce, transaksi yang terjadi dalam internet dan web. Pertukaran nilai (exchange value) yang dilakukan melalui e-commerce melibatkan hal yang berkaitan dengan barang, jasa, informasi, uang, waktu dan kenyamanan.

Kaskus diciptakan tanggal 6 Nopember 1999 oleh tiga mahasiswa asal Indonesia yaitu Andrew Darwis, Ronald, dan Budi, di Seattle, Amerika Serikat. Kaskus awalnya bertujuan sebagai forum informal mahasiswa Indonesia di luar negeri. Nama "Kaskus" sendiri merupakan singkatan dari kata "kasak-kusuk", Para anggota komunitas kaskus disebut juga dengan Kaskuser. Para kaskuser menyapa satu sama lain dengan sebutan "juragan" atau biasa disingkat "agan". Pada bulan Agustus 2005, PC Magazine Indonesia memberikan penghargaan kepada website Kaskus sebagai website terbaik dan komunitas terbesar, kemudian Kaskus terpilih kembali sebagai website terbaik pilihan pembaca PC Magazine pada 2006 (Tempo, 27 November 2011). 
Dalam forum kaskus.us, user dapat melakukan transaksi jual beli dengan sesama pengguna situs kaskus di Forum Jual Beli. Forum jual-beli ini juga dikelompokkan atas beragam jenis barang yang di tawarkan. Sehingga user yang membutuhkan transaksi jual-beli dapat langsung memilih jenis produk yang diinginkan. misalnya komputer \& notebook, handphone \& accesories, otomotif, video games pakaian, flora \& fauna, hingga perhiasan dapat dijumpai dalam forum ini.

Dalam setiap thread atau post, user penjual akan memasukkan foto sebagai display penjualan barang, dan segala informasi mengenai barang yang dijual. Untuk penjualan pakaian, di sertakan juga, jenis kain dan kualitas kain yang di jual.

Dalam forum ini juga tidak menutup kemungkinan adanya penipuan terhadap konsumen. Oleh karena itu, konsumen diharapkan memperhatikan reputasi dari penjual, yakni adanya "Cendol" atau Good Reputation Point yang berada di bawah sisi foto penjual. Semakin banyak "Cendol" semakin terpercaya dan terjaminlah barang yang akan dibeli. Begitu pula sebaliknya diberlakukan "Bata Merah" atau "Batu Bata" atau Bad Reputation Point.

Pemesanan barang di kaskus.us dilakukan menggunakan berbagai media, tergantung dari user yang melakukan penawaran. Pemesanan dilakukan via email/SMS/Telepon bahkan dengan Private Message. Sedangkan pembayaran dapat dilakukan dengan transfer, COD (Cash on Delivery) dan Kas Pay.

\section{Technology Acceptance Model (TAM)}

Technology Acceptance Model (TAM) diperkenalkan pertama kali oleh Fred D.Davis pada tahun 1986. TAM adalah sebuah teori sistem informasi yang dirancang untuk menjelaskan bagaimana pengguna mengerti dan menggunakan sebuah teknologi informasi (Davis et al., 1989). Menurut Davis (1989), tujuan utama TAM adalah untuk memberikan dasar penelusuran pengaruh faktor eksternal terhadap kepercayaan,sikap, dan tujuan pengguna. Dua variabel utama dalam TAM adalah keyakinan individual, yaitu persepsi manfaat (perceived usefulness) dan persepsi kemudahaan penggunaan (perceive easy of use) yang merupakan determinan utama dalam perilaku adopsi (perilaku untuk menggunakan) dan akhirnya penggunaan teknologi.

Menurut Davis, Bagozzi dan Warshaw (1989), TAM menganggap bahwa pengadopsian teknologi oleh pengguna ditentukan oleh dua persepsi, yaitu persepsi manfaat dan persepsi kemudahaan penggunaan. Persepsi manfaat mempunyai dampak langsung terhadap tujuan pengadopsian suatu teknologi, sedangkan persepsi kemudahan penggunaan mempunyai dampak langsung maupun tidak langsung terhadap tujuan pengadopsian melalui persepsi manfaat. Persepsi kemudahaan penggunaan sebenarnya lebih kompleks karena persepsi kemudahaan penggunaan mengukur penilaian kemudahan penggunaan (perceived easy of use) dan easy of learning dari pengguna teknologi informasi. Hasil Penelitiannya menunjukkan bahwa persepsi kemudahan penggunaan mempengaruhi persepsi manfaat.

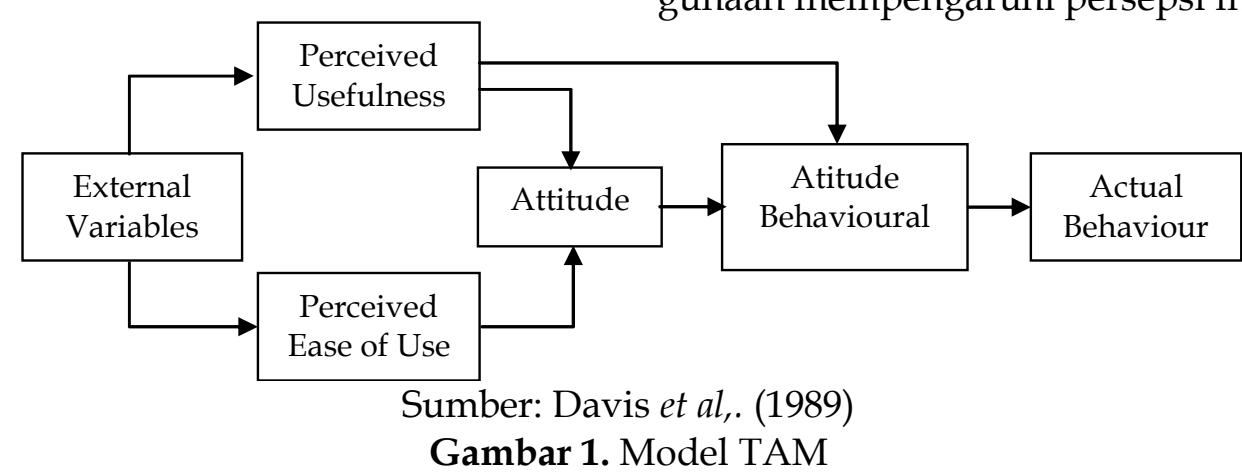




\section{Trust dalam Electronic Commerce}

Mengadopsi istilah yang digunakan Jarvenpaa dan Tractinsky (1999) penulis mendefinisikan kepercayaan (trust) pada ecommerce sebagai kesediaan konsumen untuk bergantung pada penjual dan melakukan tindakan pembelian walaupun penjual dapat dengan mudah merugikan konsumen.

Trust adalah suatu harapan bahwa pihak yang telah dipercaya tidak akan berlaku curang dengan mengambil keuntungan pribadi dalam situasi tertentu (Gefen et al., 2003). Trust merupakan keyakinan bahwa masing-masing pihak saling bergantung dan saling membutuhkan (Kumar et al., 1995). Trust berkaitan dengan keyakinan bahwa pihak yang dipercaya akan memenuhi komitmennya (Gefen et al., 2003).

Jarak jauh yang memisahkan konsumen dan situs belanja dan infrastruktur internet menghasilkan ketidakpastian dalam bertransaksi dengan e-vendor sehingga pelanggan memiliki risiko kehilangan uang dan privasinya (Pavlou, 2003). Ketidak-pastian sosial dan risiko dengan electronic vendor (e-vendor) menjadi tinggi karena perilaku e-vendor tidak dapat dimonitor (Gefen et al., 2003). Kurangnya rasa percaya menjadi alasan utama konsumen untuk tidak berhubungan dengan situs e-commerce (Pavlou, 2003).

Pavlou (2001) melakukan penelitian dengan mengembangkan dan menvalidasi model empiris untuk memprediksi niat untuk bertransaksi dengan mengintegrasikan kepercayaan pada e-commerce (EC) dengan technology acceptance model (TAM.). Sifat impersonal dari lingkungan online dan ketidakpastian teknologi internet mengurangi kontrol persepsi konsumen atas transaksi online mereka, membuat kepercayaan menjadi komponen yang tak terelakkan dari EC. Karena niat untuk menggunakan jasa retailer web untuk transaksi memerlukan unsur kepercayaan. Selain itu, kepercayaan dalam EC yang timbul terutama dari privasi menguntungkan dan persepsi keamanan dihipotesiskan untuk mengurangi risiko yang dirasakan dan secara tidak langsung mempengaruhi niat untuk bertransaksi. Penelitian tersebut memvalidasi TAM di luar tempat kerja, menunjukkan bahwa dengan memasukkan kepercayaan dalam $E C$, itu bisa meluas ke perilaku konsumen online.

\section{Perumusan Hipotesis Persepsi Privasi dan Keamanan}

Kompetensi dan membangun kepercayaan dengan proses kalkulatif merupakan teori yang menunjukkan pentingnya privasi dan keamanan sebagai anteseden persepsi kepercayaan konsumen dalam transaksi online (Doney dan Cannon, 1997). Pertama, bagi konsumen untuk membangun kepercayaan terhadap transaksi tertentu dengan retailer web, mereka menggunakan proses kompetensi untuk memastikan bahwa penjual dan infrastruktur yang terkait mampu memenuhi transaksi. Kedua, konsumen dapat melibatkan proses kalkulatif untuk menilai bahwa manfaat yang didapat oleh retailer web dari menjaga informasi pribadi mereka lebih tinggi daripada keuntungan dari tidak melakukannya. Ringkasnya, penyebab timbulnya kepercayaan konsumen terhadap sebuah transaksi adalah ketika mereka percaya bahwa retailer web dan infrastruktur yang terkait mampu melindungi informasi pribadi mereka selama pengiriman dan penyimpanan, dan juga ketika mereka percaya retailer web mendapatkan manfaat yang lebih tinggi daripada biaya dari menjaga privasi informasi dan keamanan mereka. Oleh karena itu, persepsi privasi dan keamanan cenderung positif mempengaruhi kepercayaan konsumen terhadap transaksi dengan retailer web (Pavlou, 2001).

$\mathrm{H}_{1}$ : Persepsi privasi berpengaruh positif terhadap kepercayaan dalam transaksi dengan retailer web. 
$\mathrm{H}_{2}$ : Persepsi keamanan berpengaruh positif terhadap kepercayaan dalam transaksi dengan retialer web.

\section{Kepercayaan (Trust) pada Electronic Commerce}

Semua transaksi memerlukan unsur kepercayaan, terutama yang dilakukan di lingkungan yang tidak pasti dari e-commerce (Lee 1998). Menurut Stewart et al. (2001), kepercayaan dalam transaksi elektronik didefinisikan sebagai probabilitas subjektif dimana konsumen percaya bahwa transaksi online dengan retailer web akan berlangsung secara konsisten sesuai harapan mereka. Definisi ini menangkap dua aspek yang berbeda kepercayaan di e-commerce. Pertama, pandangan tradisional melibatkan kepercayaan dalam sebuah entitas tertentu, kedua, Ini meliputi kepercayaan terhadap keandalan infrastruktur internet. Ini berarti bahwa konsumen mempertimbangkan baik karakteristik retailer web (ketidakpastian perilaku) dan juga karakteristik dari infrastruktur teknologi (ketidakpastian lingkungan). Kepercayaan telah dikaitkan dengan persepsi yang menguntungkan termasuk kepuasan meningkat, orientasi jangka panjang, dan mengurangi risiko (Ganesan, 1994). Jarvenpaa et al. (2000) menunjukkan bahwa kepercayaan di toko internet mengurangi risiko dari membeli dari toko itu.

$\mathrm{H}_{3}$ : Kepercayaan dalam transaksi online dengan retailer web berpengaruh negatif terhadap persepsi risiko transaksi tertentu.

\section{Persepsi Risiko dan Minat untuk Bertransaksi}

Minat untuk bertransaksi e-commerce di didefinisikan sebagai minat konsumen untuk terlibat dalam pertukaran nilai dengan retailer web. E-commerce memiliki beberapa dimensi yang unik dan tidak secara eksplisit tercakup oleh TAM, seperti ketidakpastian implisit menggunakan teknologi internet. Ketidakpastian meningkatkan kekhawatiran oportunisme penjual, yang sulit untuk dikontrol dalam lingkungan online. Dua jenis ketidakpastian yang hadir dalam e-commerce dan meningkatkan persepsi konsumen. Ketidakpastian perilaku muncul karena retailer web mungkin berperilaku secara oportunistik dengan mengambil keuntungan dari sifat impersonal. Sementara ketidakpastian lingkungan terjadi karena sifat tak terduga dari teknologi internet yang berada di luar kontrol konsumen (dan mungkin retailer). Teori perilaku yang direncanakan (Ajzen, 1991) memprediksi bahwa konsumen akan bersedia untuk bertransaksi jika persepsi risiko rendah. Jarvenpaa, Tractinsky, dan Vitale (2000) menyatakan bahwa risiko yang terkait dengan pembelian dari sebuah toko internet mungkin akan meningkatkan pembelian konsumen dari toko itu. Mengingat lingkungan yang tidak pasti dari e-commerce, diharapkan persepsi risiko akan menurunkan niat konsumen untuk menggunakan situs internet untuk transaksi (Pavlou, 2001).

$\mathrm{H}_{4}$ : Persepsi risiko transaksi tertentu berpengaruh negatif terhadap minat untuk bertransaksi dengan retailer web.

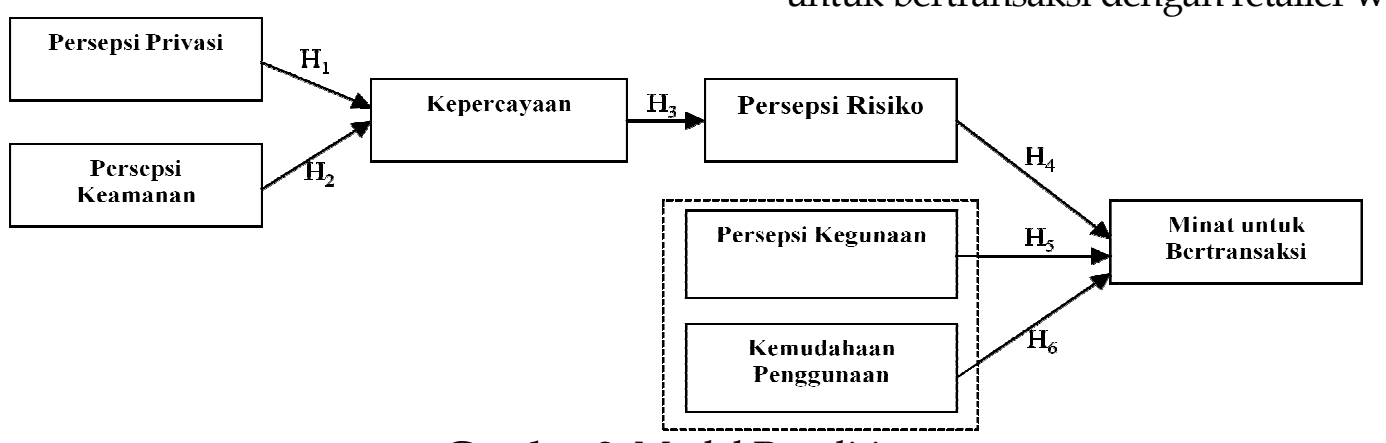

Gambar 2. Model Penelitian 


\section{Persepsi Kegunaan dan Kemudahan Penggunaan}

Minat untuk bertransaksi mengharuskan bahwa konsumen terlebih dulu menggunakan website penjual dan kemudian menyelesaikan transaksi. Bahkan jika penggunaan dan transaksi proses secara teori mungkin berbeda, mereka praktis dapat dibedakan dalam transaksi online karena konsumen menggunakan situs retailer web dengan minat untuk bertransaksi. Oleh karena itu, dibenarkan untuk menggunakan TAM sebagai model dasar untuk memprediksi minat untuk menggunakan situs web untuk transaksi online. Menurut TAM, hipotesis bahwa persepsi kegunaan dan kemudahan penggunaan memiliki pengaruh positif terhadap minat untuk bertransaksi (Pavlou, 2001).

$\mathrm{H}_{5}$ : Persepsi kegunaan berpengaruh positif terhadap minat untuk bertransaksi dengan retailer web.

$\mathrm{H}_{6}$ : Kemudahan penggunaan berpengaruh positif terhadap minat untuk bertransaksi dengan retailer web.

\section{METODOLOGI PENELITIAN Data dan Pengukuran Variabel}

Data diambil secara langsung dengan menyebarkan kuesioner melalui dua cara. Cara yang pertama yaitu penyebaran secara langsung kepada orang yang memenuhi kriteria yang ditetapkan penulis yaitu orang yang pernah melakukan ecommerce di kaskus.us yang secara kebetulan bertemu dengan penulis. Sedangkan cara yang kedua melalui surat elektronik (e-mail) atau melalui situs jejaring sosial seperti facebook. Variabel - variabel dalam penelitian dalam hal ini kepercayaan, privasi, keamanan, kepercayaan, risiko, persepsi kegunaan, dan kemudahan penggunaan diukur dengan menggunakan skala likert mulai poin 1 yang menyatakan sangat tidak setuju sampai poin 6 yang menyatakan sangat setuju. Seluruh per- tanyaan dalam pengukuran variabel diadaptasi dari Pavlou (2001).

\section{Metode Analisis Data}

Pengujian hipotesis penelitian ini menggunakan model pengujian regresi berganda dengan bantuan software SEM dengan Smart PLS. Analisis regresi pada dasarnya adalah studi mengenai ketergantungan variabel dependen (terikat) dengan satu atau lebih variabel independen (bebas) dengan tujuan mengestimasi dan/atau memprediksi rata-rata populasi atau nilai rata-rata variabel dependen berdasarkan nilai variabel independen yang diketahui (Gujarati, 2003). Adapun persamaan regresi diuraikan sebagai berikut. TRANS $=a_{0}+b_{1}$ RISK $+b_{2} U S E F+b_{3} E O U$ RISK $=a_{1}+b_{4}$ TRUST TRUST $=a_{2}+b_{5}$ PRIV $+b_{6}$ SEC

Dimana, TRANS adalah minat untuk transaksi, adalah konstanta, RISK adalah persepsi risiko, USEF adalah persepsi kegunaan, EOU adalah kemudahan penggunaan, TRUST adalah kepercayaan, $S E C$ adalah persepsi keamanan, serta PRIV adalah persepsi privasi.

Penelitian ini menggunakan dua pengolahan data yaitu dengan analisa deskriptif dan analisa analitik. Analisa deskriptif digunakan untuk menganalisa berbagai perilaku variabel berdasarkan pada berbagai teori dan pendekatan yang relevan. Sedangkan analisa analitik digunakan untuk menganalisa keterkaitan antara berbagai variabel dengan menggunakan pendekatan uji statistik berupa analisa persamaan simultan (Simultaneous Equation Model, SEM) yang dibantu dengan software smart PLS.

Uji validitas dilakukan dengan membandingkan akar kuadrat dari average variance extraced (AVE) untuk setiap konstruk dengan kolerasi antara konstruk dengan konstruk lainnya dalam model. Untuk uji reliabilitas konstruk diukur dari kriteria composite reliability. Konstruk 
dinyatakan reliabel jika nila composite reliability di atas 0,70. Uji hipotesis dilakukan dengan melihat nilai T-statistik. Hipotesis nihil ditolak apabila nilai $\mathrm{T}$ statistik lebih dari nilai T-tabel.

\section{ANALISIS DATA}

Kuesioner disebar dengan dua cara, yaitu secara langsung dan melalui link http://bit.ly/wBVPMS yang dibuat menggunakan bantuan software google docs yang telah terintegrasi dengan email. Kuesioner berupa link disebarkan peneliti melalui situs jejaring sosial seperti facebook dan twiiter, sedangkan kuesioner yang disebar secara langsung berupa selebaran yang berisi item-item pertanyaan. Dalam penelitian ini responden yang dituju oleh peneliti adalah mahasiswa Prodi Akuntansi Universitas Islam Indonesia khususnya mereka yang memiliki pengalaman menggunakan retailer web kaskus.us. Keterangan lengkap mengenai distribusi dan pengumpulan kuesioner dapat dilihat pada Tabel 1.

Tabel 1: Data kuesioner yang disebar

\begin{tabular}{lcc}
\hline Keterangan & Jumlah & $\%$ \\
\hline Kuesioner disebar langsung & 50 & 33,4 \\
$\begin{array}{l}\text { Kuesioner disebar melalui } \\
\text { link }\end{array}$ & 100 & 66,7 \\
$\begin{array}{l}\text { Kuesioner yang diisi tidak } \\
\text { lengkap }\end{array}$ & 19 & 12,7 \\
Kuesioner tidak kembali & 31 & 20,7 \\
Kuesioner yang digunakan & 100 & 66,7 \\
\hline Jumlah & 150 & \\
\hline
\end{tabular}

\section{Analisa Deskriptif Usia}

Berdasarkan usia responden terdiri dari 3 kategori, yaitu 18-21 tahun, 22-24 tahun dan $>25$ tahun. Dari hasil data yang diperoleh dan digunakan oleh peneliti, sebanyak 80 responden berusia 18-21 tahun, 20 responden berusia 22-24 tahun, dan tidak ada responden berusia di atas 25 tahun. Dari data di atas dapat disimpulkan bahwa mayoritas usia responden adalah
18-21 tahun atau sebesar $80 \%$ dari total responden.

\section{Jenis Kelamin}

Berdasarkan dari jenis kelamin responden terdiri dari 2 kategori, yaitu laki-laki dan perempuan. Dari data yang diterima dan digunakan, peneliti mendapati 60 responden berjenis kelamin laki-laki dan 40 sisanya berjenis kelamin perempuan. Dari data di atas dapat disimpulkan bahwa mayoritas responden berjenis kelamin lakilaki yaitu sebanyak $60 \%$ dari total responden.

\section{Waktu Penggunaan}

Berdasarkan lama waktu penggunaan responden terdiri dari 5 kategori, yaitu 0-2 jam/hari, 3-5 jam/hari, 6-8 jam/hari, 9-11 jam/hari dan <12 jam. Dari hasil pengumpulan data yang diterima dan digunakan oleh peneliti, sebanyak 79 responden mengakses kaskus selama 0-2 jam/hari, 18 responden mengakses 3-5 jam/hari, 2 responden mengakses 6-8 jam/hari, tidak ada responden yang mengakses 9-11 jam/hari dan 1 responden mengakses $>12$ jam/hari. Dari data yang dijelaskan di atas dapat disimpulkan bahwa mayoritas responden mengakses kaskus selama 0-2 jam/hari atau sebesar 79 $\%$ dari total 100 responden.

\section{Tempat Penggunaan}

Berdasarkan tempat penggunaan responden terdiri dari 3 kategori, yaitu rumah, warnet dan kampus. Dari data yang diperoleh dan digunakan oleh peneliti sebanyak 90 responden mengakses kaskus di rumah, 8 responden mengkases di warnet, dan 2 sisanya mengakses di kampus. Dari data yang dijelaskan di atas dapat disimpulkan bahwa mayoritas responden mengakses kaskus di rumah, yaitu sebanyak 90 responden atau sebanyak $90 \%$ dari total 100 kuesioner yang digunakan. 


\section{Kategori Barang yang Paling Sering Dibeli}

Berdasarkan kategori barang atau produk yang paling sering dibeli responden terdiri dari 11 kategori, yaitu handphone $\mathcal{E}$ acc, computer, otomotif, video games, pakaian, flora dan fauna, sports, camera, toys, perhiasan dan others. Dari data yang diperoleh dan digunakan oleh peneliti sebanyak 26 responden sering membeli kategori handphone $\mathcal{E}$ acc, sebanyak 9 responden sering membeli kategori computer, sebanyak 5 responden sering membeli kategori otomotif, 2 responden sering membeli kategori video games, 27 responden sering membeli kategori pakaian, 8 responden sering membeli kategori flora dan fauna, 2 responden sering membeli sports, 10 responden sering membeli kategori camera, 8 responden sering membeli kategori toys, 1 responden sering membeli kategori perhiasan dan 4 responden sering membeli kategori others. Dari data di atas dapat disimpulkan bahwa kebanyakan responden membeli kategori pakaian, yaitu sebanyak 27 responden atau sebanyak 27 $\%$ dari total 100 responden.

\section{Uji Validitas dan Reliabilitas Uji Validitas}

Validitas konstruk dalam penelitian ini dinilai dengan konvergen dan validitas diskriminan. Validitas konvergen dilihat dari nilai loading instrument, rata-rata variansi (AVE). Nilai loading merupakan nilai antara konstruk dan instrumen merupakan proporsi variansi dari sebuah item. Validitas dikatakan memiliki nilai yang baik berdasarkan rule of thumb jika nilai akar dari AVE untuk konstruk individual lebih besar daripada nilai korelasi antar konstruk dengan konstruk lain dalam model (Chin, 1998) dan harus lebih besar daripada nilai yang direkomendasikan yaitu 0,70 (Fornell dan Larcker, 1981). AVE loading lebih besar dari 0,70 menunjukkan bahwa nilai konstruk paling sedikit 70 persen dari ukuran variance. Untuk meng- evaluasi validitas diskriminan digunakan software PLS Graph versi 1.0.

Tabel 2: Average Variance Extracted (AVE)

\begin{tabular}{lcc}
\hline & AVE & Akar AVE \\
\hline Privasi & 0,535 & 0,731 \\
Security & 0,588 & 0,767 \\
Trust & 0,726 & 0,852 \\
Risk & 0,860 & 0,927 \\
Usefulness & 0,583 & 0,764 \\
Ease to Use & 0,505 & 0,711 \\
Intention & 0,623 & 0,789 \\
\hline
\end{tabular}

Pada Tabel 3 tampak tidak satupun dari nilai AVE yang nilainya lebih kecil dari pada 0,70. Berdasarkan hasil nilai loading AVE dapat disimpulkan bahwa validitas konvergen terpenuhi.

\section{Uji Reliabilitas}

Suatu kuesioner dikatakan reliabel atau handal jika jawaban seseorang terhadap pernyataan adalah konsisten dari waktu ke waktu (Cooper dan Schindler, 2006). Reliabilitas konstruk dalam penelitian ini akan diukur dengan menggunakan composite reliability. Suatu konstruk dikatakan reliabel jika nilai composite reliability di atas 0,70 (Ghozali, 2006).

Tabel 3: Composite Reliability

\begin{tabular}{lc}
\hline & Composite Reliability \\
\hline Privasi & 0,818 \\
Security & 0,850 \\
Trust & 0,888 \\
Risk & 0,949 \\
Usefulness & 0,848 \\
Ease to Use & 0,802 \\
Intention & 0,831 \\
\hline
\end{tabular}

Berdasarkan tabel di atas Composite reability menunjukan nilai yang memuaskan yaitu nilai masing-masing variabel di atas nilai minimum yaitu 0,70 . Berdasarkan nilai tersebut menunjukan konsistensi dan stabilitas instrumen yang digunakan sangat tinggi. Dengan kata lain dapat disimpulkan bahwa reliabilitas instrumen terpenuhi. 
Menilai Inner Model atau Model Struktural Hasil Penelitian

Menilai inner model adalah untuk mengevaluasi hubungan konstruk laten atau variabel yang telah dihipotesiskan dalam penelitian ini yaitu hal-hal yang mempengaruhi kesediaan untuk berbelanja secara online, yaitu kepercayaan, persepsi risiko, dan niat untuk bertransaksi. Berikut ini adalah perhitungan inner model dari data yang didapatkan dan digunakan oleh peneliti dengan menggunakan Partial Least Square:

Tabel 4: R-square

\begin{tabular}{lc}
\hline & R-square \\
\hline Trust & 0,317 \\
Risk & 0,205 \\
Intention & 0,471 \\
\hline
\end{tabular}

Model memberikan nilai $R$-square sebesar 0,471 pada variabel niat yang berarti bahwa variabel niat dapat dijelaskan oleh variabel persepsi risiko, persepsi kegunaan, dan kemudahan penggunaan terhadap variabel niat sebesar 0,471. Sementara itu variabel perspesi risiko dapat dijelaskan oleh variabel kepercayaan sebesar 0,205. Serta variabel kepercayaan dapat dijelaskan oleh variable persepsi privasi dan persepsi keamanan sebesar 0,553 . Selain menilai inner model juga melihat hubungan antara konstruk laten dengan memperhatikan hasil estimasi koefesien parameter path dan tingkat signifikansinya.

\section{Hasil Pengujian Hipotesis}

Dari Pengolahan data, pengujian hipotesis dapat dilakukan dengan memperhatikan tingkat signifikansinya dan parameter path antara variabel laten. Hipotesis yang diajukan untuk mengetahui hubungan masing-masing konstruk yang dihipotesiskan. Gambar 3 menunjukkan hubungan yang bervariasi. Hubungan positif terjadi pada hampir terjadi pada semua hubungan antar konstruk dengan nilai korelasi yang bervariasi. Sedangkan hubungan negatif hanya terjadi pada hubungan kepercayaan terhadap persepsi risiko dan persepsi risiko terhadap niat untuk bertransaksi secara online.

Pengambilan keputusan didasarkan pada arah hubungan dan signifikansi dari model pengujian dan korelasi antar konstruk yang ditunjukan pada Tabel 5 . Tabel tersebut merupakan output hasil dari inner weight. Hasil ini menunjukkan hubungan korelasi antar konstruk yang menghubungkan antar variabel yang membentuk sebuah hipotesis.

$\mathrm{H}_{1}$ : Persepsi privasi berpengaruh positif terhadap kepercayaan dalam transaksi dengan retailer web.

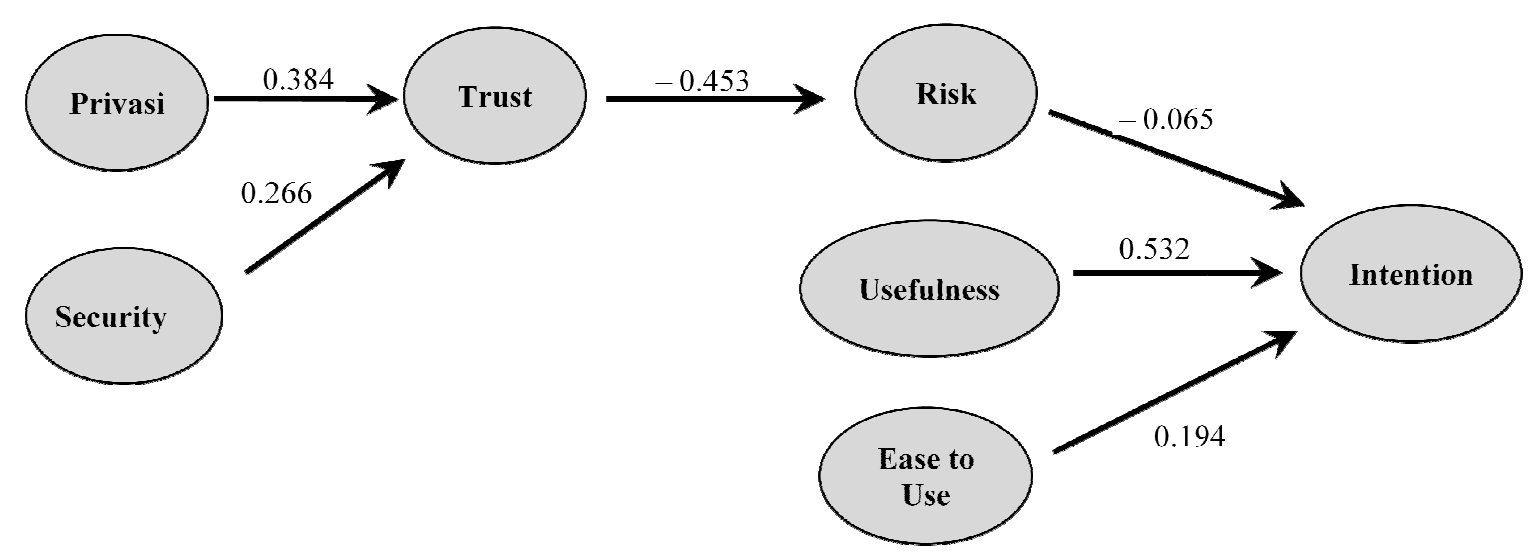

Gambar 3. Korelasi antar konstruk 
Tabel 5: Signifikansi hubungan antar variabel

\begin{tabular}{lcccc}
\hline & $\begin{array}{c}\text { original sample } \\
\text { estimate }\end{array}$ & $\begin{array}{c}\text { mean of } \\
\text { subsamples }\end{array}$ & $\begin{array}{c}\text { Standard } \\
\text { deviation }\end{array}$ & T-Statistic \\
\hline Privasi -> Trust & 0,384 & 0,398 & 0,073 & 5,231 \\
Security -> Trust & 0,266 & 0,274 & 0,074 & 3,584 \\
Trust -> Risk & $-0,453$ & $-0,465$ & 0,081 & 5,610 \\
Risk -> Intention & $-0,065$ & $-0,053$ & 0,071 & 0,913 \\
Usefulness -> Intention & 0,532 & 0,529 & 0,090 & 5,917 \\
Ease to Use -> Intention & 0,194 & 0,214 & 0,107 & 1,813 \\
\hline
\end{tabular}

Dari tabel di atas parameter hubungan antara variabel persepsi privasi terhadap kepercayaan adalah sebesar 0,384 dan nilai T satistik sebesar 5,231 (T satistik $>$ t-tabel yaitu sebesar 1,64) dengan alpha sebesar 5\%. Sehingga dapat diartikan bahwa persepsi privasi memberikan pengaruh yang Positif dan signifikan terhadap kepercayaan. Hal ini disebabkan karena ketika konsumen akan melakukan sebuah pembelian online konsumen mereka akan mempertimbangkan keamanan informasi yang mereka berikan pada kaskus yang berlaku sebagai retailer wab. Konsumen harus merasa yakin bahwa nilai yang didapat kaskus ketika menyimpan dan tidak memeberikan informasi yang diberikan kepada konsumen lebih besar daripada ketika kaskus memberikan informasi tersebut kepada pihak yang tidak berkepentingan. Untuk mengurangi risiko penyalah gunaan data pribadi tersebut, pengguna kaskus harus dilindungi secara hukum. Penggunaan informasi pribadi harus dengan persetujuan pemilik data. Atau menyediakan keamanan sistem yang dapat menjamin keamanan data pengguna. Jaminan untuk melaksanakan autentikasi dan jaminan atas integritas pesan yang dipertukarkan merupakan hal yang penting. Autentikasi yang ada di website kaskus seperti diberlakukannya sistem login menggunakan password dan username akan meningkatkan kepercayaan konsumen terhadap sistem pada kaskus. Dengan kata lain hipotesis 1 terdukung atau penelitian ini konsisten dengan hasil penelitian Pavlou (2001) yang menyatakan bahwa Persepsi privasi berpengaruh positif dengan kepercayaan terhadap transaksi dengan retailer web.

$\mathrm{H}_{2}$ : Persepsi keamanan berpengaruh positif terhadap kepercayaan dalam transaksi dengan retialer web.

Dari tabel di atas parameter hubungan antara variabel persepsi keamanan terhadap kepercayaan adalah sebesar 0,266 dan nilai $\mathrm{T}$ satistik sebesar 3,584 (T satistik > t-tabel yaitu sebesar 1,64) dengan alpha sebesar $5 \%$. Sehingga dapat diartikan bahwa persepsi keamanan memberikan pengaruh yang positif dan signifikan terhadap kepercayaan. Hal ini disebabkan karena ketika konsumen akan memutuskan untuk melakukan pembelian online, konsumen akan memeperhitungkan kompetensi kaskus dalam menyelesaikan setiap transaksinya. Hal ini menjadi acuan dalam menentukan tingkat keamanan dalam pembelian online dalam website kaskus, yang berpengaruh secara langsung terhadap penjual ataupun sistem dalam kaskus. Kaskus harus menjaga keamanan konsumen dari kerugian-kerugian, terutama kerugian moneter. Dalam hal ini kaskus meyediakan jasa pihak ketiga yaitu jasa rekber. Rekber atau rekening bersama merupakan pihak yang dapat menjembatani setiap transaksi jual beli dalam webiste kaskus. Rekber bertugas untuk menyimpan uang pembayaran selama barang dikirim oleh penjual kepada pembeli, ketika barang sudah sampai ditangan pembeli dan barang memenuhi kriteria penjualan makan pihak penjual dapat mencairkan uang yang disimpan oleh jasa rekber. E-commerce harus mampu mena- 
warkan keamanan yang setara dengan keamanan dalam dunia nyata. Dengan kata lain hipotesis 2 terdukung atau penelitian ini konsisten dengan hasil penelitian sebelumnya yang ditulis oleh Pavlou (2001) yang menyatakan bahwa Persepsi keamanan berpengaruh positif dengan kepercayaan terhadap transaksi dengan retialer web.

$\mathrm{H}_{3}$ : Kepercayaan dalam transaksi online dengan retailer web berpengaruh negatif dengan persepsi risiko transaksi tertentu.

Dari tabel di atas parameter hubungan antara variabel kepercayaan terhadap persepsi risiko adalah sebesar 0,453 dan nilai $\mathrm{T}$ satistik sebesar 3,584 ( $\mathrm{T}$ satistik > t-tabel yaitu sebesar 1,64 ) dengan alpha sebesar 5\%. Sehingga dapat diartikan bahwa kepercayaan memberikan pengaruh yang negatif dan signifikan terhadap persepsi risiko. Kepercayaan merupakan dasar dari berbagai macam hubungan termasuk hubungan jual beli. Risiko yang dihadapi keonsumen ketika bertransaksi secara online lebih besar daripada ketika konsumen bertransaksi saecara langsung. Hal ini dikarenakan konsumen tidak dapat mengevaluasi prilaku toko online secara langsung. Konsumen enggan melakukan transaksi secara online dengan toko online yang tidak mereka kenal dengan baik. Kedekatan dan transparansi hubungan antara penjual dan pembeli akan meningkatkan kepercayaan kepada konsumen. Pada hal ini kaskus menyediakan fitur private message untuk mendekatkan hubungan antara penjual dengan pembeli, sehingga penjual dan pembeli dapat berkomunikasi dengan bebas tanpa diketahui oleh pihak-pihak lain. Selain itu, kaskus menggunakan fitur Great Reputation Point dan Bad Reputation Point pada setiap penjual dalam website kaskus hal ini bertujuan untuk memudahkan calon konsumen dalam menilai reputasi seorang seller. Dengan kata lain hipotesis 3 terdukung atau penelitian ini konsisten dengan penelitian Pavlou (2001) yang menyatakan bahwa Kepercayaan terhadap transaksi online dengan retailer web berpengaruh negatif dengan persepsi risiko transaksi tertentu.

$\mathrm{H}_{4}$ : Persepsi risiko transaksi tertentu berpengaruh negatif terhadap minat untuk bertransaksi dengan retailer web.

Dari tabel di atas parameter hubungan antara variabel persepsi risiko terhadap minat untuk bertransaksi adalah sebesar -0,065 dan nilai $\mathrm{T}$ satistik sebesar 0,913 (T satistik < t-tabel yaitu sebesar 1,64) dengan alpha sebesar 5\%. Sehingga dapat diartikan bahwa persepsi risiko memberikan pengaruh yang negatif dan tidak signifikan terhadap minat untuk bertransaksi. Hal ini dikarenakan pelanggan tidak memiliki kesempatan untuk mempelajari perilaku retailer web dan produk yang dibelinya secara online. Untuk memprediksi risiko yang dihadapi konsumen, sebelum melakukan transaksi konsumen berusaha untuk mengumpulkan informasi mengenai retailer web tersebut. Berdasarkan informasi tersebut konsumen dapat memprediksi seberapa besar risiko yang dihadapinya. Semakin banyak informasi yang diperoleh mengenai toko online yang bersifat positif, semakin kecil risiko yang dirasakan sehingga semakin besar kemungkinan untuk melakukan transaksi secara online. Tetapi, Kaskus merupakan retailer web yang memiliki nilai kegunaan yang besar dengan biaya atau harga yang relatif rendah. Sebagian besar barangbarang yang dijual dalam website kaskus tidak diperjual belikan di toko-toko nyata. Hal-hal inilah yang menyababkan pada akhirnya pembeli berpersepsi bahwa tingginya risiko yang mungkin terjadi tidak lebih besar dari nilai yang didapatkan dalam website kaskus. Dengan kata lain hipotesis 4 tidak terdukung atau penelitian ini tidak konsisten dengan hasil penelitian Pavlou (2001) yang menyatakan bahwa Persepsi risiko transaksi tertentu 
berpengaruh negatif terhadap minat untuk bertransaksi dengan retailer web.

$\mathrm{H}_{5}$ : Persepsi kegunaan berpengaruh positif terhadap minat untuk bertransaksi dengan retailer web.

Dari tabel di atas parameter hubungan antara variabel persepsi kegunaan terhadap minat untuk bertransaksi adalah sebesar 0,532 dan nilai $\mathrm{T}$ satistik sebesar 5.917 ( $\mathrm{T}$ satistik > t-tabel yaitu sebesar 1,64) dengan alpha sebesar 5\%. Sehingga dapat diartikan bahwa persepsi kegunaan memberikan pengaruh yang positif dan signifikan terhadap minat untuk bertransaksi. Hal ini disebabkan kerana pada dasarnya setiap individu akan berusaha memenuhi setiap kebutuhannya.

Keterbatasan waktu dan tenaga menjadikan pembelian secara online sangat bermanfaat dan efektif. Karena retailer web bisa di akses dimana saja melalui jaringan internet. Barang dan jasa yang diperjual belikan dalam kaskus sangat banyak dan beragam dari barang baru bekas, bahkan barang-barang langka yang tidak diperjual belikan pada toko-toko nyata. Harga barang yang diperjual belikan dalam kaskus cenderung lebih murah karena penjual dalam kaskus tidak menggunakan biaya yang banyak. Alasan inilah yang menyebabkan kaskus memiliki nilai kegunaan yang lebih. Dengan kata lain hipotesis 5 terdukung atau penelitian ini konsisten dengan hasil penelitian sebelumnya yang ditulis oleh Pavlou (2001) dan Davis (1989) yang menyatakan bahwa Persepsi kegunaan berpengaruh positif terhadap minat untuk bertransaksi dengan retailer web.

$\mathrm{H}_{6}$ : Kemudahan penggunaan berpengaruh positif terhadap minat untuk bertransaksi dengan retailer web.

Dari tabel di atas parameter hubungan antara variabel persepsi kegunaan terhadap minat untuk bertransaksi adalah sebesar 0,194 dan nilai $\mathrm{T}$ satistik sebesar 1,813 ( $\mathrm{T}$ satistik $>\mathrm{t}$-tabel yaitu sebesar 1,64) dengan alpha sebesar $5 \%$. Sehingga dapat diartikan bahwa persepsi kegunaan memberikan pengaruh yang positif dan signifikan terhadap minat untuk bertransaksi. Era globalisasi menuntut manusia untuk berfikir semakin modern dan mengikuti perkembangan teknologi. Teknologi hampir menyentuh dan mempengaruhi semua aspek kehidupan termasuk aktifitas jual beli. Kemudahaan sistem yang ditawarkan membantu individu untuk menilai pengorbanan secara material maupun non material. Kompleksitas sebuah sistem akan mengurangi minat pengguna, karena tingginya komlpeksitas sebuah sistem memerlukan banyak pemikiran. Sistem harus memberikan petunjuk-petunjuk penggunaan dan informasi yang jelas. Dalam website kaskus disediakan forum jual beli, dimana didalam forum ini kaskus telah mengkelompokkan barang dan jasa yang diperjual belikan kedalam kategori yang berbeda-beda dan memberikan fasilitas kolom pencarian, dua hal ini ditujukan untuk memudah konsumen dalam mencari barang atau jasa yang diinginkan. Kaskus menggunakan thread sebagai lapak, dalam thread ini penjual dapat mendeskripsikan produk yang mereka tawarkan dalam bentuk kalimat ataupun gambar. Sistem dalam kaskus menyediakan layanan upload image sehingga pembeli tidak perlu mendatangi barang untuk melihat kondisi barang yang dijual. Dengan kata lain hipotesis 6 terdukung atau penelitian ini konsisten dengan penelitian sebelumnya yang ditulis oleh Pavlou (2001) dan Davis (1989) yang manyatakan bahwa Kemudahan penggunaan berpengaruh positif terhadap minat untuk bertransaksi dengan retailer web.

\section{KESIMPULAN DAN SARAN}

Dari penelitian ini dapat disimpulkan bahwa model penelitian yang diajukan terdukung dan hampir dari semua hipo- 
tesis yang diajukan. Hanya ada satu hipotesis yang tidak terbukti dan tidak didukung oleh data yang diperoleh yaitu hipotesis persepsi risiko transaksi tertentu berpengaruh negatif terhadap minat untuk bertransaksi dengan retailer web. Hipotesis persepsi kegunaan berpengaruh positif terhadap minat untuk bertransaksi dengan retailer web memiliki pengaruh yang paling signifikan diantara hipotesis yang lainnya. Saran bagi penelitian selanjutnya adalah penambahkan variabel, misalnya: variabel reputasi web dan memperluas sampel penelitian, sehingga dapat memberikan hasil yang lebih luas dan mencakup segala lapisan masyarakat yang menggunakan retailer web kaskus.us.

\section{DAFTAR PUSTAKA}

Ajzen, I., (1991), "The Theory of Planned Behavior," Organizational Behavior and Human Decision Processes (50), pp. 179-211.

Brynjolfsson, E. and Smith, M., (2000), "Frictionless Commerce? A Comparison of Internet and Conventional Retailers," Management Science (46:4), pp. 563-585.

Cooper, D.R. and Schindler, P.S., (2006), Bussines Research Methods ninth edition. McGraw Hill, International Edition

Chin, W.W. (1998), "The Partial Least Squares Approach for Structural Equation Modeling", In Marcoulides, G.A. (Ed), Modern Method for Business Resaearch, Mahwah. NJ. Erlbaum Associates, hal. 295 - 358.

Davis, F. D., (1989), "Perceived Usefulness, Perceived Ease of Use and User Acceptance of Information Technology," MIS Quarterly (13:3), pp. 319-340.

Davis, Fred D; Bagozi, R.P; and Warsaw, P.R. 1989. “User Acceptance of Computer Technology : A Comparison of Two Theoritical Models.", Management Sciences, August 1989.

Doney, P. M., and Cannon, J. P. ,(1997), “An Examination of the Nature of Trust in BuyerSeller Relationships," Journal of Marketing (61:1), April, pp. 35-51.

Friedman, B., P.H. Kahn, Jr., dan Howe, D.C., (2000), “Trust online”, Communications of the ACM 43 Vol. 12, 34-40.

Fornell, C., dan Larcker, D. (1981), “Evaluating Structural Equation Models with Unobservable Variable and Measurement Error", Journal of Marketing Research, Vol. 18, hal. $39-50$

Ganesan, S., (1994), "Determinants of Long-Term Orientation in Buyer-Seller Relationships," Journal of Marketing, (58), pp. 1-19.

Gefen, David., Karahanna, Elena dan Straub, Detmar W., (2003), “Trust And Tam In Online Shopping: An Integrated Model", MIS Quarterly, March 51-90.

Ghozali, Imam, (2006), Structural Equation Modeling Metode Alternatif dengan Partial Least Square, Badan Penerbit Universitas Diponegoro.

Gujarati, D.N. (2003). Basic Econometrics. Singapore: McGraw-Hill, Inc.

Hoffman, D. L., T. P. Novak and M. Peralta, (1999), "Building consumer trust online," Communications of the ACM (42:4), pp. 80-85. 
Jarvenpaa, S. L., N. Tractinsky and M. Vitale, (2000), "Consumer Trust in an Internet Store", Information Technology and Management (1:12), pp. 45-71.

Jarvenpaa, S.L., dan Tractinsky, N., (1999), “Consumer trust in an Internet store: Acrosscultural Validation", Journal of Computer-Mediated Communication, Dec., pp. 1-35.

Kumar, N., Scheer, L.K. and Stenkamp, J.B.E.M., (1995), “The Effect of Suppliers Fairness on Vulnerable Resellers", Journal of Marketing Research, Feb., pp. 54-65.

Lee, H. G., (1998), “Do Electronic Marketplaces Lower the Price of Goods?" Communications of the ACM (41:1), pp. 73-80.

McKnight, D. H., Choudhury, V., dan Kacmar, C. (2002), “Developing and Validating Trust Measures for E-Commerce: An Integrative Typology", Information Systems Research, 13:3, 334-359.

Moon, J-M and Y-G Kim, (2001), “Extending the TAM for a World-Wide-Web context," Information and Management (28), pp. 217-230.

Pavlou, Paul A., (2003), “Consumer Acceptance of Electronic Commerce: Integrating Trust and Risk with theTechnology Acceptance Model", International Journal of Electronic Commerce, Spring, pp. 101-134.

Pavlou, Paul, (2001), "Integrating Trust in Electronic Commerce with the Technology Acceptance Model: Model Development and Validation". Amcis 2001 proceedings.

Stewart, D. W., P. A. Pavlou and S. Ward, (2001), "Media Influences on Marketing Communications," In Media Effects: Advances inTheory and Research, J. B. a. D. Zillmann (Ed.), Erlbaum, Hillsdale, N. J.

Tempo, (2011). “Dunia Bermain Para Juragan”. 21-27 November, hlm. 41-43.

Urbaczewski, A., Jessup L.M., dan Wheeler, B., (2002), “Electronic Commerce Research: A Taxonomy and Synthesis". Journal Of Organizational Computing And Electronic Commerce 12(4), pp. 263-305. 